\title{
Roles of career maturity mediating the effects of locus of control and socioeconomic status on career readiness
}

\author{
Mar'atus Sholikah, Muhyadi \\ Department of Economics Education, Faculty of Economics, Universitas Negeri Yogyakarta, Indonesia
}

\begin{tabular}{l}
\hline \hline Article Info \\
\hline Article history: \\
Received Oct 15, 2020 \\
Revised Jun 14, 2021 \\
Accepted Jul 16, 2021 \\
\hline
\end{tabular}

\section{Keywords:}

Career maturity

Career readiness

Locus of control

Socioeconomic status

\begin{abstract}
This study aimed to analyze students' readiness for careers out of their professions by considering the effect of locus of control and socioeconomic status. Career maturity acted as the variable intervening. The quantitative method was chosen to test the hypothesis. A total of 80 students were selected to be respondents based on purposive sampling. Model testing was done by using PLS-SEM. The findings of this study found that the locus of control influenced student career readiness. Conversely, socioeconomic status had no significant effect on their career readiness. On the other hand, this study's career maturity partially mediates between locus of control and career readiness. Regarding the effect of socioeconomic status on career readiness, career maturity in this study was known to have a role as an explanatory or predictor. This study concluded that if students wanted to improve their career readiness, they should pay attention to the locus of control and achieve career success. This study's results contribute to institutions, educators, students, and counselling, informing that individual career maturity is an effective way to facilitate students' readiness in their career decision-making process. Future studies should adopt essential variables related to career readiness that is not examined in this study.
\end{abstract}

This is an open access article under the CC BY-SA license.

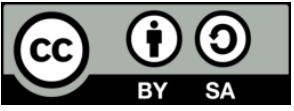

\section{Corresponding Author:}

Mar'atus Sholikah

Postgraduate Program, Department of Economics Education

Universitas Negeri Yogyakarta

Jalan Colombo 1, Depok, Sleman, D. I. Yogyakarta 52281, Indonesia

Email: maratussholikah.2019@ student.uny.ac.id

\section{INTRODUCTION}

Significant changes in education, technology, environment, global economy, demographics, and immigration patterns impact the increasingly rapid transformation of the world of work, which is more diverse and less predictable. In line with Savickas and Porfeli, they explained that the transformation in nature and work context had experienced rapid growth [1]. However, many companies or work organizations are now not concerned about whether their education synchronized with their job. Some companies had outsourced some of their functions, preferring contract workers and workers who could be moved more flexibly [1].

The recent economic downturn has left many people out of work and more vulnerable to job instability, impacting their well-being. As a result, many scholars now argue that developing relevant psychological strengths to overcome challenges during a career transition is necessary. Savickas, et al. used career readiness and maturity abilities to develop psychological strength, where the four dimensions that underlie career readiness are crystallizing, exploring occupations, deciding, and preparing [2]. Meanwhile, Savickas and Porfeli stated that the four dimensions underlined career maturity were a concern, control, 
curiosity, and confidence [1]. Guan, et al. had found that career readiness and adaptability played an essential predictor of career success and success in applying for a job vacancy, salary, and career satisfaction [3].

Career readiness and maturity are theoretically defined as resources to adapt, which indicates a willingness to undertake tasks and change status [1]. Career adaptations show that individuals have more readiness to develop their abilities more effectively. Career readiness and adaptability are conceptualized as a combination of a proactive personality and optimism. Previous research has found several career readiness indicators and adaptation, including big-five personality, proactive personality, and self-esteem [4]. Another opinion, such as in research conducted by Sholikah, et al. [5], found that social and psychological factors influence one's career readiness and maturity. In this case, social factors include the parent's socioeconomic status, while psychological factors, for example, are the locus of control.

Based on these factors and the theory of the big-five factors or five-factor model (FFM), locus of control is defined as one of the characteristics of development in the concept of personality [5]. Akpchafo's definition was reinforced by locus of control, who explained that locus of control was a significant factor in exploring behavior and personality [6]. Some researchers suggest that locus of control is one factor that significantly influences career readiness and individual achievement [7], [8]. Therefore, the locus of control becomes a reference for individual behavior in determining the decision to choose a career [9]. Likewise, with Zhou, et al. findings, his research's career locus of control is explained as one of the criteria for success in achieving career life [10]. Strauser, et al. findings also confirmed that locus of control could increase a person's participation and persistence in preparing for their career [11]. Previous findings also proved that this locus of control significantly affected one's career readiness [12].

Socioeconomic status also affects various dimensions of an individual's life [13]. Socioeconomic status is including the opportunity for having a career [14]. Socioeconomic status often limits a person's choices and goals in achieving his goals. However, socioeconomic status in career development literature is rarely studied, even though previous studies have found that socioeconomic status affects how individuals perceive opportunities and affect their access to education and development [15]. Blustein also conducted a study related to school-to-work transition on 20 study participants (average age $=21$ years) [16]. The findings of Blustein reported that high socioeconomic background influenced interest in work, better self-concept, greater access to resources, and more significant career adaptation compared to individuals with lower socioeconomic status [16]. This study investigated the direct and indirect effects of career readiness, locus of control, socioeconomic status, and career maturity based on the above explanation. The locus of control concept, in this case, represents psychological factors, while socioeconomic status represents social factors. Thus, this research can contribute insights into how career maturity can mediate the influence of locus of control and socioeconomic status on student career readiness.

\section{RESEARCH METHOD}

\subsection{Respondents and data collection}

In this study, quantitative methods were used to test theoretical models and hypotheses. The research sample consisted of all students of the Office Administration Education Study Program. The data collection process took place at Semarang State University during the 2017/2018 academic year by purposive sampling. The criteria used to determine the research sample include students who attended all practical and theoretical courses during their time as students. Therefore, the sample used consisted of the seventhsemester active students, 80 respondents. Data were collected through a questionnaire that was distributed online to students voluntarily with their consent. The total number of valid responses was 80 . This number has met the requirements for conducting the model analysis. The assessment of the questions asked in the questionnaire was based on a liker scale ( $1=$ strongly disagree; $5=$ strongly agree).

\subsection{Measurement instruments}

In this study, an online survey via Google Form was used to ensure its confidentiality and effectiveness. The questionnaire in this study was arranged in two parts. The first part is an introduction, while the second part contains a list of questions. The introductory section informs a series of questions regarding the respondent's demographic data, including gender, age, work experience, parental education, occupation, and income levels.

The questions section is arranged on a Likert scale ranging from 1 to 5 (1=strongly disagree; $5=$ strongly agree) and consists of 38 items developed in such a way as to measure the construction of the model based on previous literature with slight adjustments related to the object of research. The variables measured in this study consisted of career readiness out of the profession (REA), career maturity (CAR), locus of control (LOC), and socioeconomic status (SES). Those are described in Table 1. 
Table 1. Measurement indicators of constructs

\begin{tabular}{cccc}
\hline Constructs & & Indicators & Source \\
\hline Career readiness outside the teaching profession & REA1 & Crystallizing & {$[2]$} \\
& REA2 & Exploring occupations & \\
& REA3 & Deciding & \\
Career maturity & REA4 & Preparing & Concern \\
& CAR1 & Control & \\
& CAR2 & Curiosity & \\
Locus of control & CAR3 & Confidence & \\
& CAR4 & Internality & \\
& LOC1 & Helplessness & \\
& LOC2 & LOC3 & Examination/preparation \\
Socio-economic status & LOC4 & Luck & \\
& SES1 & Education levels & Income levels \\
& SES2 & Residence & \\
\hline
\end{tabular}

\subsection{Research hypothesis}

The hypotheses relating to the research model were formulated as:

H1: Locus of control directly affects the career readiness out of the teaching profession.

$\mathrm{H} 2$ : Socioeconomic status directly affects career readiness out of the teaching profession.

H3: Locus of control directly affects career readiness out of the teaching profession mediated by career maturity.

H4: Socioeconomic status directly affects career readiness out of the teaching profession mediated by career maturity.

\subsection{Data analysis}

The modelling used to test the model was structural equation modelling (SEM), considering that the data obtained meets the test requirements for using SEM with Partial Least Squares. The selection of the analysis method is because PLS is a method of data analysis based on assumptions such as data does not have to be normally distributed, and the sample does not have to be large, this means that the number of samples is less than 100 can be analyzed [19]-[21]. Reinforced by Marcoulides, et al. if data analysis uses PLS-SEM, the minimum sample size is based on the maximum number of arrows pointing to latent variables and significance levels [22]. The study had nine arrows pointing to latent variables and used a significance level of $95 \%$, resulting in a minimum sample size of $78-80$ respondents. Thus, the number of respondents as many as 80 respondents can represent the research population. So, the use of PLS-SEM in this study is because this methodology is considered the most appropriate and most adequate. Therefore, the SmartPLS 3.0 software was used for analyzing data in this research.

\section{RESULTS AND DISCUSSION}

\subsection{Demographic characteristics}

A total of 110 questionnaires were distributed to respondents. As many as 30 of them were used for trials while the rest or 80 questionnaires were used for further analysis. Table 2 shows the demographic results of the respondents. The 80 respondents consisted of men (18.8\%) and women $(81.2 \%)$, and the age that dominated is 21 years. The table informs that most of the respondents' parents have low incomes. 
Table 2. Demographic data of respondents

\begin{tabular}{ccccc}
\hline Attributes & Classification & Percent & Mean & SD \\
\hline Gender & Male & $18.8 \%$ & 1.81 & 0.393 \\
Age & Female & $81.2 \%$ & & \\
& 20 & $27.5 \%$ & 1.85 & 0.638 \\
& 21 & $61.3 \%$ & & \\
Work experience in industrial & 22 & $10.0 \%$ & & \\
& 23 & $1.3 \%$ & & \\
Father's income & Yes & $60.0 \%$ & 1.40 & 0.493 \\
& No & $40.0 \%$ & & \\
& None & $12.5 \%$ & 2.53 & 1.147 \\
& $\leq$ IDR 1,500,000 & $53.8 \%$ & & \\
& IDR 1,501,000 to IDR 2,500,000 & $11.3 \%$ & & \\
Mother's income & IDR 2,500,000 to IDR 3,500,000 & $13.8 \%$ & & \\
& $\geq$ IDR 3,501,000 & $8.8 \%$ & & \\
& None & $48.8 \%$ & 1.83 & 1.053 \\
& IIDR 1,500,000 & $32.5 \%$ & & \\
& IDR 1,501,000 to IDR 2,500,000 & $10.0 \%$ & & \\
& IDR 2,500,000 to IDR 3,500,000 & $5.0 \%$ & & \\
& $\geq$ IDR 3,501,000 & $3.8 \%$ & & \\
& & &
\end{tabular}

\subsection{Confirmatory factor analysis}

\subsubsection{Questionnaire reliability}

The study used the Split-Half, Composite Reliability, and Cronbach Alpha Coefficients to ensure the instrument's consistency and stability. The Split-Half and Cronbach Alpha coefficients were tested with SPSS 24 software, and Composite Reliability was tested with SmartPLS 3.0 software. The value of all three was higher than 0.70 , so it was reliable [23]. Table 3 shows that the instrument had a value higher than 0.70.

Table 3. Validity and reliability $(\mathrm{n}=30)$

\begin{tabular}{cccccc}
\hline Variable & Split-Half & $\alpha$ & CR & KMO & Sig. \\
\hline CAR & 0.923 & 0.972 & 0.979 & 0.771 & 0.000 \\
LOC & 0.820 & 0.949 & 0.963 & 0.702 & 0.000 \\
REA & 0.746 & 0.957 & 0.954 & 0.703 & 0.000 \\
SES & 0.935 & 0.935 & 0.972 & 0.882 & 0.000 \\
\hline
\end{tabular}

\subsubsection{Questionnaire validity}

Since the instrument had a theoretical basis, the research had to test the validity of its construction using confirmatory factor analysis. The questionnaire contained four latent variables, namely CAR, LOC, SES, and REA. Further analysis, the KMO value of all dimensions was higher than 0.70 , and the significance was lesser than 0.01. Thus, the research data could be used for the research. The KMO value is displayed in Table 3. The loading factor value that was under 0.70 should be removed [19]. Therefore, Table 4 displays the loading factor values in each variable. All items have a loading factor value of $0.714-0.954$. It means that all items in the category are valid because the loading factor value is more than 0.70 [19]. 
Table 4. Loading factor $(\mathrm{n}=30)$

\begin{tabular}{|c|c|c|c|c|c|}
\hline Item & Loading factor & AVE & Item & Loading factor & AVE \\
\hline CAR1.4 & 0.755 & 0.524 & LOC1.1 & 0.716 & 0.566 \\
\hline CAR1.5 & 0.897 & & LOC 1.2 & 0.749 & \\
\hline CAR1.6 & 0.741 & & LOC2.3 & 0.843 & \\
\hline CAR2.1 & 0.767 & & LOC 2.4 & 0.766 & \\
\hline CAR2.2 & 0.858 & & LOC 2.5 & 0.744 & \\
\hline CAR2.4 & 0.764 & & LOC 3.2 & 0.817 & \\
\hline CAR2.5 & 0.792 & & LOC 3.3 & 0.714 & \\
\hline CAR3.1 & 0.784 & & LOC4.3 & 0.863 & \\
\hline CAR3.2 & 0.874 & & REA1.5 & 0.759 & 0.693 \\
\hline CAR3.3 & 0.780 & & REA1.6 & 0.760 & \\
\hline CAR3.4 & 0.791 & & REA2.1 & 0.717 & \\
\hline CAR3.5 & 0.828 & & REA2.2 & 0.774 & \\
\hline CAR4.2 & 0.793 & & REA3.1 & 0.799 & \\
\hline CAR4.3 & 0.718 & & REA3.2 & 0.764 & \\
\hline CAR4.4 & 0.765 & & REA4.3 & 0.751 & \\
\hline \multirow[t]{6}{*}{ CAR4.5 } & 0.721 & & SES1.3 & 0.907 & 0.812 \\
\hline & & & SES1.4 & 0.890 & \\
\hline & & & SES2.1 & 0.903 & \\
\hline & & & SES2.2 & 0.880 & \\
\hline & & & SES3.1 & 0.954 & \\
\hline & & & SES3.2 & 0.869 & \\
\hline
\end{tabular}

\subsection{Measurement model assessment}

The next step was the measurement model assessment to confirm the construction's reliability and validity. Reliability is a test that determines how much an instrument's consistency is in measuring a concept [24]. Reliability analysis is assessed from Cronbach's Alpha and Composite Reliability. Cronbach's Alpha range is 0.906-0.953 and the Composite Reliability range value is 0.933-0.965. Both reliability values are above 0.70 as in Table 5 [23]. Validity analysis assessed the convergent validity and discriminant validity.

Convergent validity is the degree used to measure an approved item. It is like the statement [23] that convergent validity is assessed based on factor loading, composite reliability, and average variance extracted, as shown in Table 5. According to Hair, et al., the loading value for all items should be more than 0.6, and the recommended composite validity value should be more than 0.7 [23]. Meanwhile, the average variance extracted (AVE) value should be more than the recommended value of 0.5 [23].

Discriminant validity helps determine the extent to which items are differentiated between constructions or measuring different concepts [25]. As presented in Table 6, it is seen that all the roots of AVE are higher than the tolerated values in the rows and columns, which indicates that the discriminant validity is sufficient. The study also used HTMT value testing to determine the discriminant validity. Table 6 shows that the HTMT value is lower than the acceptable threshold of 0.90 . All items are categorized as valid.

Table 5. Reliability and convergent validity

\begin{tabular}{cccccc}
\hline Constructs & Indicators & Loading & CR & Cronbach's Alpha & AVE \\
\hline Career readiness & REA1 & 0.885 & 0.933 & 0.906 & 0.777 \\
& REA2 & 0.867 & & & \\
& REA3 & 0.876 & & & \\
& REA4 & 0.898 & & 0.953 & 0.874 \\
Career maturity & CAR1 & 0.908 & 0.965 & & 0.623 \\
& CAR2 & 0.967 & & & \\
& CAR3 & 0.933 & & & \\
Locus of control & CAR4 & 0.932 & & & \\
& LOC1 & 0.859 & 0.943 & 0.923 & \\
& LOC2 & 0.934 & & & \\
& LOC3 & 0.907 & & & \\
& LOC4 & 0.891 & & & \\
Socio-economic status & SES1 & 0.913 & 0.956 & & \\
& SES2 & 0.955 & & & \\
& SES3 & 0.942 & & & \\
\end{tabular}

Table 6. Discriminant validity

\begin{tabular}{ccccccccc}
\hline \multirow{2}{*}{ Constructs } & \multicolumn{9}{c}{ Fornell-Larcker } & HTMT & & & \\
& CAR & LOC & REA & SES & CAR & LOC & REA & SES \\
\hline CAR & 0.973 & & & & & & & \\
LOC & 0.921 & 0.935 & & & 0.795 & & & \\
REA & 0.893 & 0.880 & 0.895 & & 0.671 & 0.772 & & \\
SES & 0.790 & 0.804 & 0.830 & 0.844 & 0.141 & 0.837 & 0.634 & \\
\hline
\end{tabular}




\subsection{Structural model assessment}

The structural model shows the existence of a causal correlation of variables in the model. The model includes approximate path coefficients indicating the hypothesized correlation's strength and the $\mathrm{R}$-square value determining the model's predictive strength. Path coefficients ( $\beta$ value and significance) and R-square show how well the data support the hypothesized model [26]. Figure 1 and Table 7 illustrate the structural model results from the PLS-SEM output. LOC in this test is known to have a significant and positive effect on REA $(\mathrm{H} 1: \beta=0.337, \mathrm{p}<0.021)$. These results differ from SES, which has no significant effect on REA $(\mathrm{H} 2: \beta=0.333, \mathrm{p}>0.264)$. Furthermore, CAR mediates the effect of LOC on REA (H3: $\beta=0.042, p<0.038$ ), where CAR is only acted as a predictor of the effect of SES on REA (H4: $\beta=0.218$, $\mathrm{p}>0.340$ ). Therefore, the test results support $\mathrm{H} 1$ and $\mathrm{H} 3$ and do not support $\mathrm{H} 2$ and $\mathrm{H} 4$ as shown in Table 7.

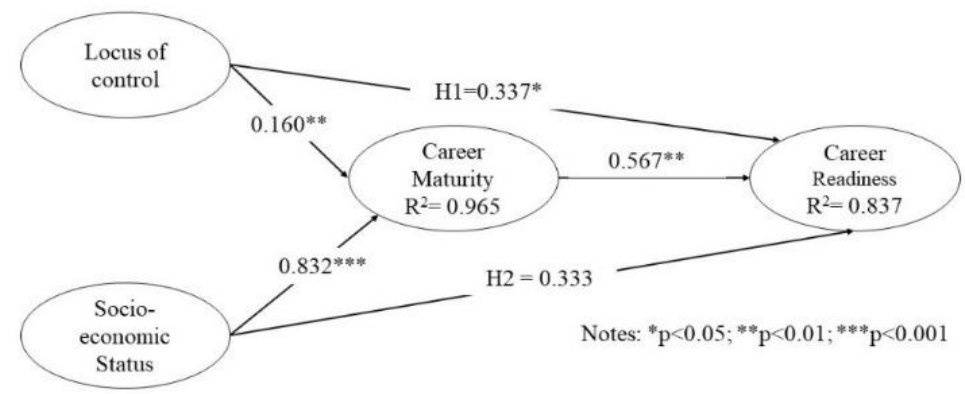

Figure 1. The correlation of locus of control and socioeconomic status on job readiness outside the teaching profession mediated by career maturity

Table 7. Summary of hypothesis testing results

\begin{tabular}{ccccc}
\hline Hypotheses & Path coefficient & t-value & p-value & Decision \\
\hline LOC $\rightarrow$ REA & 0.337 & 2.309 & 0.021 & Supported \\
SES $\rightarrow$ REA & 0.333 & 1.119 & 0.264 & Not supported \\
LOC $\rightarrow$ CAR $\rightarrow$ REA & 0.042 & 4.846 & 0.038 & Supported \\
SES $\rightarrow$ CAR $\rightarrow$ REA & 0.218 & 0.956 & 0.340 & Not supported \\
\hline
\end{tabular}

\subsection{Discussion}

This study examined the role of students' career maturity in mediating locus of control and socioeconomic status on career readiness and career decision-making abilities out of the profession. Based on Goldberg's theory of The Big Five Factor or Five-Factor Model (FFM), locus of control (LOC) is defined as one of the developments in the concept of personality. Reinforced by Gadassi, et al. [8], the locus of control is a significant factor in exploring behavior and personality. According to previous research, a person's personality could improve a person's performance in the world of work [27], [28]. Added by August, individual personalities and behavior greatly influenced their career readiness and achievements [29].

Therefore, the locus of control becomes a reference for individual behavior in determining the decision to choose his career [9]. It supported the self-determination theory [30], in which the locus of control positively affected career decision-making because individuals with a high locus of control had the motivation and passion for achieving goals. In line with Zhou, et al. findings, career locus of control was one criterion for achieving a career life [10]. Furthermore, Strauser, et al. found that the locus of control could increase a person's participation and persistence in preparing for their career [11]. According to Guan, et al. the higher the locus of individual control, especially the internal locus of control, the greater their tendency to increase their work readiness [31]. Therefore, the locus of control was used to intervene in work readiness outside the teaching profession. In this study, the variable locus of control (LOC) was measured by adopting the career locus of control scale, which included four indicators, namely internality, helplessness, examination/preparation, and luck [32], [33].

The data processing results in Table 7 show that the locus of control had a significant positive effect on work readiness because the p-value is 0.021 , where the value is less than 0.05 and has an estimated value of 0.337 . Therefore, the hypothesis that the locus of control had a significant positive effect on students' readiness to work outside the teaching profession was proven or accepted. The amount of direct influence given by the variable locus of control on student readiness to work outside the teaching profession was $33.7 \%$. Thus, students' locus of control positively influenced the success in preparing for careers to predict their career decisions. This finding is consistent with previous research, which states that locus of control 
contributes significantly to career readiness [12], [34]. This study's results are supported by previous research findings, which concluded that locus of control positively and significantly affects student career readiness in the industrial era 4.0 [35].

The second hypothesis stated that socioeconomic conditions had a positive effect on work readiness. Socioeconomic conditions were among the most critical factors affecting a person's academic achievement and employment status [36]. Socioeconomic status (SES) reflected family income, parental education, housing conditions, and social positions [37]. Individuals from higher SES tended to aspire to high levels of education and prestigious occupations [38], and they would engage in systematic exploration and career planning activities to achieve their expectations [16]. In contrast, individuals from lower SES were likely to experience financial distress, considering economic factors when planning their educational and career goals and options [36]. In this study, socioeconomic conditions were measured using three indicators, namely education, income, and housing levels [37], [39]. Meanwhile, the data processing results in Table 7 describe the positive effects of variable socioeconomic conditions positively toward students' readiness to work outside the teaching profession. It was proven by the p-value of 0.264 , higher than 0.050 , and the estimated value of 0.333 .

Thus, hypotheses that revealed socioeconomic conditions positively affected work readiness outside the teaching profession were not proven or rejected. The amount of direct influence was found in the variable socioeconomic conditions on work readiness outside the teaching profession is $33.3 \%$. On the other hand, this study's results do not support the socioeconomic status of career readiness. It occurs because the socioeconomic status only affects, but not significantly on career readiness. These findings support previous studies, where socioeconomic status has a positive and insignificant effect on readiness to plan a future career [40], [41]. This study also found that career maturity fully mediates the relationship between locus of control and career readiness. These results are consistent with Zhou, et al. [10] who stated that understanding career maturity provides support for career readiness and mediates career readiness and locus of control.

\subsection{Theoretical and practical implications}

The study results found that career readiness was associated with individual success in balancing work and life, locus of control, and socioeconomic status. On the one hand, these results support positive attitudes such as locus of control on career decision making [5]. Thus, it can be said that locus of control is an attribute that influences one's career success. A higher internal locus of control influences most students who have career readiness and success. Given that the internal locus of control is related to ability and effort, it makes them more likely to develop relevant abilities in achieving career outcomes and career preparation [42]. Sari stated that there is a higher possibility of internal locus of control on career development, which in time will strengthen the higher level of career readiness [43]. However, external locus of control does not have a significant effect on individual career readiness. Due to the possibility that one's career development cannot be wholly controlled by themselves, there is a possibility of detrimental effects on their effort. The findings obtained from the study indicate that there is no significant effect of socioeconomic status on career readiness. These findings suggest that the relationship between the two variables may involve different mechanisms. High socioeconomic status cannot motivate career behavior. Otherwise, the low socioeconomic status may motivate individuals to develop their career behavior so that the effect of these socioeconomic statuses is not significant to one's career readiness.

This study's findings indicate that the locus of control can help students increase their readiness to take proactive action in developing their career abilities. For this reason, educators, institutions, and counsellors of higher education should consider adopting a framework of career readiness, locus of control, and socioeconomic status to diagnose problems faced by students related to their career development and preparation. Besides, career maturity fully mediates the locus of control on student readiness in making career decisions. It indicates that individual career maturity must be an effective way to facilitate students' readiness in their career decision-making process.

\subsection{Limitations and recommendations for further research}

There are several limitations to this study. First, the findings are based on a sample of students at one university in Indonesia, so these findings cannot be generalized to all other Indonesian students. It is because Indonesia has cultural diversity. The thinking styles of students who are influenced by cultural differences may also affect their career success, locus of control, and career maturity. Compared to western students such as Australia, British, and America, Indonesian students had different personal abilities to decide their career choices. Generally, at the age of 18 , western students were considered adults, so they tended to decide for themselves, including making future decisions [44]. Meanwhile, Indonesian students should consider and discuss their career choice with parents, counsellors, lecturers, and friends before setting career decisions. 
For this reason, the influence of locus of control on the career readiness of Indonesian students is not comparable in Western society. The second limitation of this study is related to the mediation variables studied in this study obtained from students. For further research, it is best to be able to expand to other models. Further research should also adopt essential variables related to career readiness, such as vocational interest, self-regulation, and academic engagement. It is recommended to apply other research designs, such as experimental designs.

\section{CONCLUSION}

Apart from this study's limitations, there is a contribution to the current literature related to examining what roles of career maturity in mediating the effect of locus of control and socioeconomic status on career readiness out of the profession. The results showed that locus of control had a significant positive effect on career readiness, strongly supported by the tests carried out in this study. These findings differ from socioeconomic status, which has no significant effect on career readiness, as found in this study. On the other hand, the role of career maturity partially mediates the effect given by locus of control on career readiness. Conversely, career maturity only acts as a predictor in mediating socioeconomic status on career readiness. Thus, these findings have explained that career readiness, career maturity, and locus of control play a crucial role in shaping their career abilities to succeed in their careers.

\section{ACKNOWLEDGEMENTS}

This study was supported and financed by the Indonesia Endowment Fund for Education (LPDP).

\section{REFERENCES}

[1] M. L. Savickas and E. J. Porfeli, "Career Adapt-Abilities Scale: Construction, reliability, and measurement equivalence across 13 countries," J. Vocat. Behav, vol. 80, no. 3, pp. 661-673, 2012.

[2] M. L. Savickas, E. J. Porfeli, T. L. Hilton, and S. Savickas, "The Student Career Construction Inventory," J. Vocat. Behav, vol. 106, no. January, pp. 138-152, 2018.

[3] Y. Guan, W. Yang, X. Zhou, Z. Tian, and A. Eves, "Predicting Chinese human resource managers' strategic competence: Roles of identity, career variety, organizational support, and career adaptability," J. Vocat. Behav, vol. 92, pp. 116-124, 2016.

[4] A. E. M. van Vianen, U. C. Klehe, J. Koen, and N. Dries, "Career adapt-abilities scale - Netherlands form: Psychometric properties and relationships to ability, personality, and regulatory focus," J. Vocat. Behav., vol. 80, no. 3, pp. 716-724, 2012.

[5] M. Sholikah, Muhyadi, S. Indartono, O. B. Kenzhaliyev, and G. K. Kassymova "Self-Efficacy and Student Achievement for Enhancing Career Readiness: the Mediation of Career Maturity," J. Pendidik. Teknol. dan Kejuru., vol. 27, no. 1, pp. 15-25, 2021.

[6] G. O. Akpchafo, "Locus of control as correlate of career decision making among secondary school students in Delta State of Nigeria," J. Educ. Soc. Res., vol. 7, no. 2, pp. 25-30, 2017.

[7] B. Chhabra and R. P. Mohanty, "Moderating role of locus of control in the relationship between job satisfaction and organisational citizenship behaviour: a study of the Indian IT sector," Int. J. Indian Cult. Bus. Manag., vol. 13, no. 3, p. 288, 2016.

[8] R. Gadassi, I. Gati, and H. Wagman-Rolnick, "The adaptability of career decision-making profiles: associations with self-efficacy, emotional difficulties, and decision status," J. Career Dev., vol. 40, no. 6, pp. 490-507, 2013.

[9] C. Dumitriu, I. C. Timofti, E. Nechita, and G. Dumitriu, "The influence of the locus of control and decisionmaking capacity upon the leadership style," Procedia - Soc. Behav. Sci., vol. 141, pp. 494-499, 2014.

[10] W. Zhou, Y. Guan, L. Xin, M. C. K. Mak, and Y. Deng, "Career success criteria and locus of control as indicators of adaptive readiness in the career adaptation model," J. Vocat. Behav., vol. 94, pp. 124-130, 2016.

[11] D. Strauser, D. Waldrop, J. Hamsley, and W. Jenkins, "The role of self-efficacy and locus of control in job readiness training programs," J. Prev. Assess. Rehabil., vol. 10, pp. 243-249, 1998.

[12] N.-R. Kim and K.-H. Lee, "The effect of internal locus of control on career adaptability: The mediating role of career decision-making self-efficacy and occupational engagement," J. Employ. Couns., vol. 55, no. 1, pp. 2-15, 2018.

[13] S. R. Ali, E. H. McWhirter, and K. M. Chronister, "Self-efficacy and vocational outcome expectations for adolescents of lower socioeconomic status: A pilot study," J. Career Assess., vol. 13, no. 1, pp. 40-58, 2005.

[14] N. A. Fouad, S.-Y. Kim, A. Ghosh, W. Chang, and C. Figueiredo, "Family influence on career decision making: Validation in India and the United States," J. career Assess., vol. 24, no. 1, pp. 197-212, 2016.

[15] M. E. Kelly, "Social cognitive career theory as applied to the school-to-work transition," Ph.D. Dissertation, Seton Hall University, 2011.

[16] D. L. Blustein, “A relational theory of working," J. Vocat. Behav., vol. 79, no. 1, pp. 1-17, 2011.

[17] R. Millar and M. Shevlin, "The development and factor structure of a career locus use with school pupils," $J$. Career Dev., vol. 33, no. 3, pp. 224-249, 2007. 
[18] G. M. Lawson, J. T. Duda, B. B. Avants, J. Wu, and M. J. Farah, "Associations between children's socioeconomic status and prefrontal cortical thickness," Dev. Sci., vol. 16, no. 5, pp. 641-652, 2013.

[19] J. F. J. Hair, G. T. M. Hult, C. M. Ringle, and M. Sarstedt, A primer on partial least squares structural equation modeling (PLS-SEM), 2nd ed. SAGE Publications, 2017.

[20] I. Ghozali, Structural Equation Modeling, Metode Alternatif dengan Partial Least Square (PLS). Semarang: Badan Penerbit Universitas Diponegoro, 2014.

[21] J. Henseler, C. M. Ringle, and M. Sarstedt, "A new criterion for assessing discriminant validity in variance-based structural equation modeling," J. Acad. Mark. Sci., vol. 43, no. 1, pp. 115-135, 2015.

[22] G. A. Marcoulides, C. Saunders, and B. G. A. Marcoulides, "Editor' s comments : PLS: A silver bullet?" MIS Q., vol. 30, no. 2, pp. 2-9, 2006.

[23] J. F. J. Hair, W. C. Black, B. J. Babin, and R. E. Anderson, Multivariate data analysis. Pearson Prentice Hall, 2014.

[24] I. Ghozali and H. Latan, Partial least squares: Concepts, techniques and applications using the SmartPLS 3.0 program for empirical research, (in Bahasa). Semarang: Badan Penerbit Universitas Diponegoro, 2015.

[25] J. F. Hair, M. Sarstedt, C. M. Ringle, and J. A. Mena, "An assessment of the use of partial least squares structural equation modeling in marketing research," J. Acad. Mark. Sci., vol. 40, no. 3, pp. 414-433, 2012.

[26] F. Prayoonphan and X. Xu, "Factors influencing the intention to use the common ticketing system (spider card) in Thailand," Behav. Sci. (Basel)., vol. 9, no. 5, 2019.

[27] J. Ahmad, M. R. Ather, and M. Hussain, "Impact of big five personality traits on job performance (organizational commitment as a mediator)," International Conference on Management, Knowledge and Learning, 2014, pp. 571-577.

[28] S. Leephaijaroen, "Kasetsart Journal of Social Sciences Effects of the big-five personality traits and organizational commitments on organizational citizenship behavior of support staff at Ubon Ratchathani Rajabhat University," Kasetsart J. Soc. Sci., vol. 37, no. 2, pp. 1-8, 2016.

[29] R. A. August, "Understanding Career Readiness in College Student-Athletes and Identifying Associated Personal Qualities," J. Career Dev., vol. 47, no. 2, pp. 177-192, 2020.

[30] R. M. Ryan and E. L. Deci, "Intrinsic and Extrinsic Motivations: Classic Definitions and New Directions," Contemp. Educ. Psychol., vol. 25, pp. 54-67, 2000.

[31] Y. Guan, et al., "Career Locus of Control and Career Success Among Chinese Employees: A Multidimensional Approach," J. Career Assess., vol. 21, no. 2, pp. 295-310, 2013.

[32] S. D. Permatasari and O. Usman, "Influence of locus of control, self-efficacy,and career guidance on students career maaturity," J. Econ. Educ. Off. Adm. Account., 2019, doi: 10.2139/ssrn.3637492.

[33] W. Zhou, Y. Guan, L. Xin, M. Chi, K. Mak, and Y. Deng, "Career success criteria and locus of control as indicators of adaptive readiness in the career adaptation model," J. Vocat. Behav., vol. 94, pp. 124-130, 2016.

[34] F. N. Kholifah and N. U. Hadi, "Analysis of the internship program, interest in the teaching profession, and locus of control on readiness to become educators for students of the STKIP PGRI Tulungagung Economic Education study program who are taking the 2017/2018 thesis," (in Bahasa), J. Manag., vol. 5, no. 2, pp. 205-219, 2017.

[35] A. A. S. D. Saraswati, I. G. A. M. A. D. Putri, H. B. Suprasto, and M. M. R. Sari, "Influence of competence and locus of control on the readiness of accounting department students facing the world of work era industrial revolution 4.0," Int. Res. J. Manag. IT Soc. Sci, vol. 7, no. 4, pp. 14-23, 2020.

[36] J. Metheny and E. H. McWhirter, "Contributions of Social Status and Family Support to College Students' Career Decision Self-Efficacy and Outcome Expectations,” J. Career Assess., vol. 21, no. 3, pp. 378-394, 2013.

[37] K. N. Kim and S. H. Oh, "Effects of social constraints on career maturity: The mediating effect of the time perspective," Asia Pacific Educ. Rev., vol. 14, no. 2, pp. 221-229, 2013.

[38] R. J. Gagnon, "Examining overparenting, socioeconomic status, and parental out-of-school time experience: Does socioeconomic status and out-of-school-time experience matter?" Child. Youth Serv. Rev., vol. 101, pp. 181-189, 2019.

[39] J. M. Jacobs-lawson, E. L. Waddell, and A. K. Webb, "Predictors of Health Locus of Control in Older Adults," Curr. Psychol., vol. 30, pp. 173-183, 2011.

[40] Y. Ariyanti and P. A. Bowo, "The influence of internship, family socioeconomic status, and self-efficacy on job readiness," (in Bahasa), Econ. Educ. Anal. J., vol. 7, no. 2, pp. 671-687, 2018. [Online]. Available: https://journal.unnes.ac.id/sju/index.php/eeaj/article/view/28283.

[41] G. Tong, E. Persons, and A. L. Harris, "Getting ready ahead: socioeconomic status and parenting strategies among Chinese adolescents with emigration intentions," J. Ethn. Migr. Stud., pp. 1-23, 2020, doi: 10.1080/1369183X.2020.1759404.

[42] Y. Guan, et al., "Career adaptability, job search self-efficacy, and outcomes: A three-wave investigation among Chinese university graduates," J. Vocat. Behav., vol. 83, no. 3, pp. 561-570, 2013.

[43] R. Sari, "The career readiness as a teacher on university students based on locus of control, self esteem, and pedagogical competence," Talent. J. Psikol., vol. 4, no. 2, pp. 156-166, 2019.

[44] J. W. Santrock, Adolescence. Penn Plaza, New York: McGraw-Hill Education, 2016. 